\title{
Addressing the language needs of industry: Incorporating real-life workplace communication into SGC-based vocational English modules
}

\author{
Annie Lai-kun Choi \\ From Practical Social and Industrial Research (PSIR) Symposium 2014 \\ Wanchai, Hong Kong. 5 December 2014
}

\begin{abstract}
Background
For vocational English courses to adequately address the language needs of today's industries, it is of vital importance to incorporate into the course materials and classroom activities details and characteristics of the real-world communication tasks that trade practitioners are required to perform in their workplaces [1]. As part of a recent study conducted by the Languages Discipline entitled the Industry Language Training Needs (ILTN) Study, this paper examines how authentic workplace communicative events derived from the qualitative data collected directly shed light on the language needs of industry, and it explores ways of translating the findings into practical pedagogical uses for the existing SGC-based Vocational English modules of the various programs offered by the Vocational Training Council (VTC).
\end{abstract}

\section{Methods}

The industry sectors involved in the study include catering, communication design, customer services, hotel, human resources, leisure and sports, merchandising, retailing, sales and marketing, tourism, etc. This paper focusses on an analysis of the data collected through semi-structured interviews with industry practitioners and workplace observations, together with the authentic trade texts obtained from the industries.

\section{Results}

Drawing on a synthesis of Halliday's [2] triad construct of context of situation in systemic functional linguistics and Douglas' [3] construct of discourse domain as a theoretical framework alongside the Specification of Generic

Correspondence: annielk@vtc.edu.hk

Languages Planning and Development Office, Vocational Training Council, Hong Kong
(Foundation) Competencies (English) (SGC) [4], the analysis found that the numerous specific communicative events (when studied in conjunction with the contextual details) derived from the data, such as replying to email/ telephone enquiries, handling complaints, writing reports and proposals, taking part in discussions and meetings/ negotiations, giving presentations, etc., are of various levels of complexity and familiarity and require language output of different levels of sophistication. Upon systematically mapping these real-life workplace communication tasks with the corresponding units of competency (UoCs) in the SGC according to the language skills/competency elements involved and the QF levels into which these tasks fit, the majority of these communicative events were found to cluster around those UoCs that are covered in the English curricula of the various VTC programs. This lends substantial empirical support for the relevance of these English modules to the generic language competencies needed in the actual workplace.

Examples from the analyzed data will be used to illustrate how details of these real-life workplace communicative events, especially contextual dimensions including the subject matters, participants/interlocutors and modes of communication that essentially determine language use, can be translated into actual pedagogical tasks for vocational language training, particularly within a framework of outcomes-based teaching and learning [5], and how this facilitates the constructive alignment between the intended learning outcomes, teaching and learning activities and assessment tasks of the existing SGC-based vocational English modules.

\section{Conclusions}

The paper concludes by recommending that a resource bank of authentic workplace communicative events be 
developed as a practical means of support for vocational English teaching and curriculum development, pointing towards more research-led professional practice for vocational language training.

\section{Published: 4 December 2014}

\section{References}

1. Evans S: Designing tasks for the business English classroom. ELT Journal 2013, 67(3):281-293.

2. Halliday MAK: Language as social semiotic: The social interpretation of language and meaning. London, England: Edward Arnold; 1978.

3. Douglas D: Assessing language for specific purposes. Cambridge, England: Cambridge University Press; 2000.

4. Education Bureau, Hong Kong SAR Government.: Specification of generic (foundation) competencies (English) [Internet]., c-2008 [cited 2014 May 30]. Available from: http://www.hkqf.gov.hk/guie/SCS.asp.

5. Biggs J, Tang C: Teaching for quality learning at university. Maidenhead, England: Open University Press/McGraw Hill; 2007.

doi:10.1186/2193-1801-3-S1-O6

Cite this article as: Choi: Addressing the language needs of industry: Incorporating real-life workplace communication into SGC-based vocational English modules. SpringerPlus 2014 3(Suppl 1):O6.

\section{Submit your manuscript to a SpringerOpen ${ }^{\mathcal{O}}$ journal and benefit from:}

- Convenient online submission

- Rigorous peer review

- Immediate publication on acceptance

- Open access: articles freely available online

- High visibility within the field

- Retaining the copyright to your article 